\title{
PRODUCTION OF H2 AND METHANOL VIA DARK FERMENTATION. A PROCESS OPTIMIZATION STUDY.
}

Borja Hernándeza , Cristina García Blázqueza, Valentina Aristizábal-Marulanda ${ }^{b}$ Mariano Martína .

a Departamento de Ingeniería Química y Textil, Universidad de Salamanca, Plaza Caídos 1-5, 37008, Salamanca, España.

b Facultad de Tecnologías, Escuela de Tecnología Química, Grupo de Desarrollo de Procesos Químicos, Universidad Tecnológica de Pereira, Pereira, Colombia.

\section{PARAMETERS AND STATISTICS OF THE THREE KINETIC MODELS STUDIED.}

This section provides a comparison of different kinetic models used for modelling the dark fermentation reaction. Despite three reactions, Eq. (S-1) to (S-3), occur during dark fermentation, the process has been traditionally modelled with a single kinetic model that considers one overall reaction. In the current work this Monod's model together with $1^{\text {st }}$ order and Andrew's models have been extended including the three competitive reactions that take place in dark fermentation, Eqs. (S-1) to (S-3). In the current work this Monod's model together with $1^{\text {st }}$ order and Andrew's models have been extended including the three competitive reactions that take place in dark fermentation, Eqs. (S-1) to (S-3). These models have been evaluated before including them in the process optimization. Since no data is available for validating the components generated by the third reaction, an efficiency term is included, $\eta_{\text {gluctogas }}$. It takes into account the fraction of substrate that is decomposed following the kinetic equations (S-1) and (S-2). The remaining fraction is assumed to follow Eq. (S-3). Apart from this assumption, the concentration of bacteria is also assumed constant for Monod's and Andrew's models.

The parameters for the models of this reaction are determined based on data from the literature [1]. In Monod's and Andrew's models a single parameter combining the maximum yield, $\mu_{\max }$, and the microorganism concentration is determined since no data is available for the concentration of it. The parameter estimation tool from gProms $®$ v.5.0 has been used for this task. This dynamic optimization 
approach used for determining the parameters has been carried out assuming different standard deviations to identify the maximum deviation for each model. The results from these studies are presented in Table S-1 and Figure S-1. It can be seen that the first order kinetic model can be used to describe the process $\left(X^{2}\right.$ model is smaller than $X^{2}$ critical $)$ if a relative standard deviation of $15 \%$ is allowed. In the case of Monod's and Andrew's models both allow to describe the model up to relative standard deviations of $10 \%$, reducing the error in the standard deviation of the $1^{\text {st }}$ order model. Comparing these two cases it can be seen that the $X^{2}$ model is a bit smaller in the Andrew's model, which ensures a bit more accuracy in describing the physics.

$$
\begin{aligned}
& \mathrm{C}_{6} \mathrm{H}_{12} \mathrm{O}_{6}+2 \mathrm{H}_{2} \mathrm{O}+\mathrm{H}_{2} \mathrm{O} \rightarrow 2 \mathrm{CH}_{3} \mathrm{COO}^{-}+2 \mathrm{H}^{+}+2 \mathrm{CO}_{2}+4 \mathrm{H}_{2} \\
& \mathrm{C}_{6} \mathrm{H}_{12} \mathrm{O}_{6} \rightarrow \mathrm{CH}_{3} \mathrm{CH}_{2} \mathrm{CH}_{2} \mathrm{COO}^{-}+\mathrm{H}^{+}+2 \mathrm{CO}_{2}+2 \mathrm{H}_{2} \\
& \mathrm{C}_{6} \mathrm{H}_{12} \mathrm{O}_{6}+2 \mathrm{NADH} 2 \mathrm{CH}_{3} \mathrm{CH}_{2} \mathrm{COO}^{-}+2 \mathrm{H}_{2} \mathrm{O}+2 \mathrm{NAD}^{+}
\end{aligned}
$$

A)

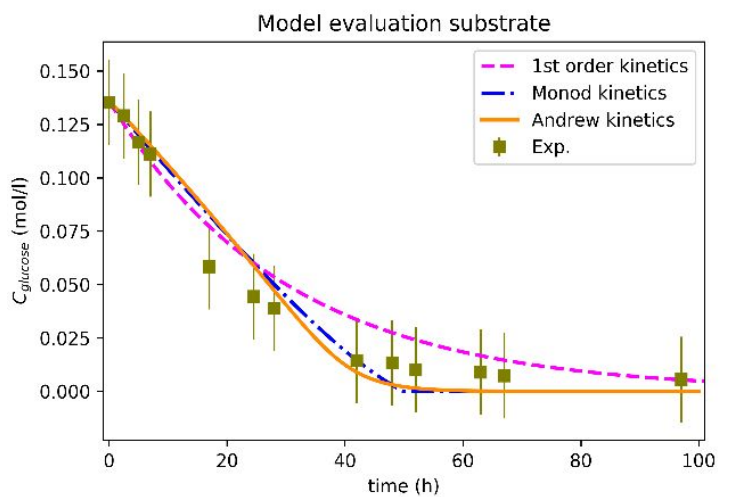

B)

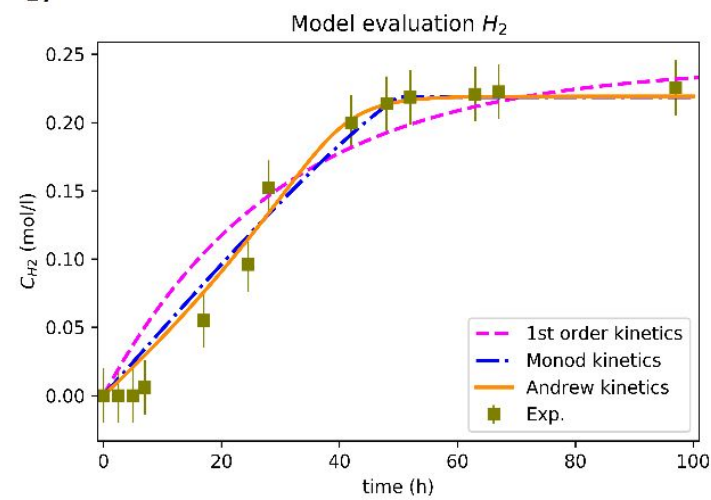

Figure S-1. Comparative modelling analysis with substrate (a) and $\mathrm{H}_{2}(\mathrm{~b})$ for $1^{\text {st }}$ order, Monod and Andrew's kinetic models in dark fermentation. 
Table S-1. Summary of kinetic parameters.

\begin{tabular}{|c|l|c|l|c|l|}
\hline \multicolumn{2}{|l|}{$1^{\text {st }}$ Order kinetic model } & \multicolumn{2}{l|}{ Monod's model } & \multicolumn{2}{l|}{ Andrew's model } \\
\hline$\eta_{\text {gluctogas }}$ & 0.532501 & $\eta_{\text {gluctogas }}$ & 0.52379 & $\eta_{\text {gluctogas }}$ & 0.52379 \\
\hline $\mathrm{k}_{1}$ & 0.00655016 & $\mu_{\max 1} \cdot X_{o}$ & 0.00215392 & $\mu_{\text {max } 1} \cdot X_{o}$ & 0.0366915 \\
\hline $\mathrm{k}_{2}$ & 0.0267512 & $k_{s 1}$ & 0.0301813 & $K_{s 1}$ & 1.09574 \\
\hline & & $\mu_{\max 2} \cdot X_{o}$ & 0.00146968 & $k_{s 11}$ & 0.0135172 \\
\hline & & $k_{s 2}$ & $1 \mathrm{e}-5$ & $\mu_{\text {max } 2} \cdot X_{o}$ & 0.0309876 \\
\hline & & & & $K_{s 2}$ & 0.202768 \\
\hline$X^{2}$ model & 26.8185 & $X^{2}$ model & 26.0001 & $X^{2}$ model & 25.9973 \\
\hline$X^{2}$ critical & 33.9244 & $X^{2}$ critical & 31.4104 & $X^{2}$ critical & 30.1435 \\
\hline
\end{tabular}

\section{MODELING OF THE COST OF THE DISTILLATION COLUMN}

For integrating the computation of the cost of the column within the code, the Fenske-Underwood-Gilliland (FUG) short-cut method is adapted.

The number of stages is computed as in Eq. (S-4). It assumes that the methanol recovered in the distillate and the residue of the tower are fixed. The distillate is assumed to have a methanol volume concentration ( $\left.y_{L K}\right)$ of $99 \%$ and the residue a concentration of water of $99 \%$. The volatility of the light component, methanol, $\left(v_{L K}\right)$ is computed assuming that the tower operates at atmospheric pressure.

$N_{S}=\frac{\log \left(\left(\frac{y_{L K}}{y_{H K}}\right)_{d} \cdot\left(\frac{y_{H K}}{y_{L K}}\right)\right)}{\log \left(v_{L K}\right)}$

The efficiency per plate is assumed to be 1.8. As a result, the total number of plates is fixed to 23 .

The minimum reflux ratio is computed as presented in Eq. (S-5). In that Eq. (S-5), $\Phi$, is a parameter obtained interpolating in Eq. (S-6). Assuming that the inlet stream enters in the column as saturated vapor, the reflux ratio is only dependent on the composition of the feed. Since the iteration for determining the value of $\Phi$ cannot be addressed within the optimization model, the computation of the minimum reflux ratio is included in the optimization following the reduced model presented in Eq. (S-7), which can be used between molar fractions of 0.1 and 0.8 . In Figure S-2, a comparison of the prediction is addressed. 


$$
R_{\min }+1=\sum_{i=1}^{n} \frac{v_{i} y_{i d}}{v_{i}-\Phi}
$$

$1-q=\sum_{i=1}^{n} \frac{v_{i} \cdot y_{i F}}{v_{i}-\Phi}$

$R_{\text {min }}=-0.9824-7.688 \cdot \log \left(x_{\text {MetOH Feed }}\right)$

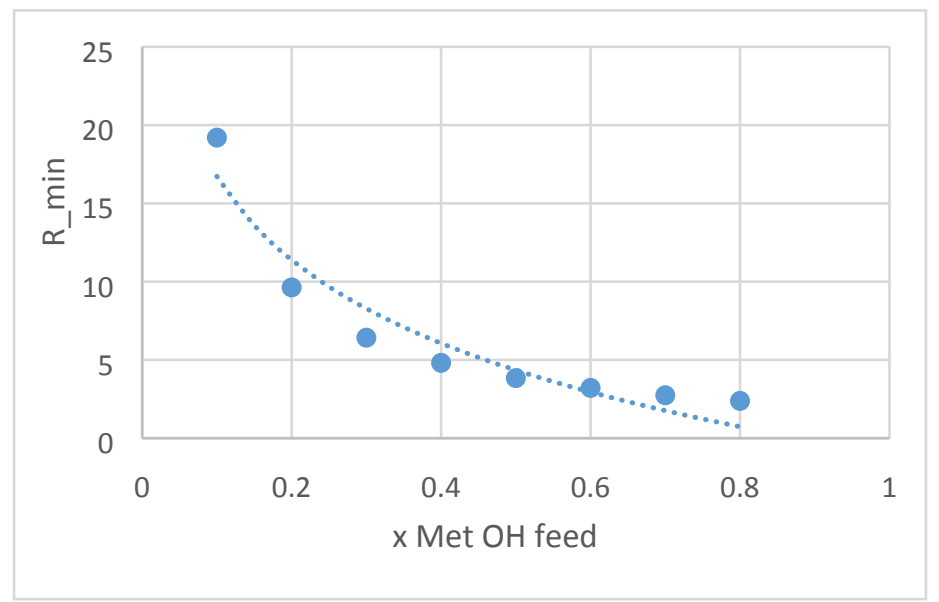

Figure S-2. Fitting of the minimum reflux ratio as function of the molar concentration of methanol in the feed.

Once the number of stages and the reflux ratio, which is 1.2 times the minimum reflux ratio, have been computed. The cost of the column is computed as presented by [2]. However, the equations developed in that approach are too complex to be addressed within the optimization code since they include powers, square roots and inverse functions. Thus, an evaluation is carried out for different mass fluxes (between $1 \times 10^{-6} \mathrm{~kg} / \mathrm{s}$ to $0.01 \mathrm{~kg} / \mathrm{s}$ ) and different reflux ratios (from 2 to 15 ). The results from this evaluation are then reduced by Bayesian Information Criteria minimization with ALAMO including simple and power terms of order 2 [3]. A BIC minimization is carried out including only the potential form of the feed since the potential form of the reflux leads to errors in the optimization since it is previously computed from a logarithm. Thus, Eq. (S-8), which can be addressed within the optimization code, is used in the optimization. The parity plot of this equation is showed in Figure S-3 and the most relevant statistical parameters of the model are summarized in Table S-2.

$\operatorname{Cost}(\$)=2799364.9 * F_{\text {feed }}+331.95 * R+152.57$ 
Table S.-2. Summary of quality parameters for the model of the column cost.

\begin{tabular}{|l|l|}
\hline \multicolumn{1}{|c|}{ Statistical metric } & \multicolumn{1}{c|}{ Value } \\
\hline Root mean square error & 3230 \\
\hline $\mathrm{R}^{2}$ & 0.725 \\
\hline $\mathrm{BIC}$ & 1050 \\
\hline
\end{tabular}

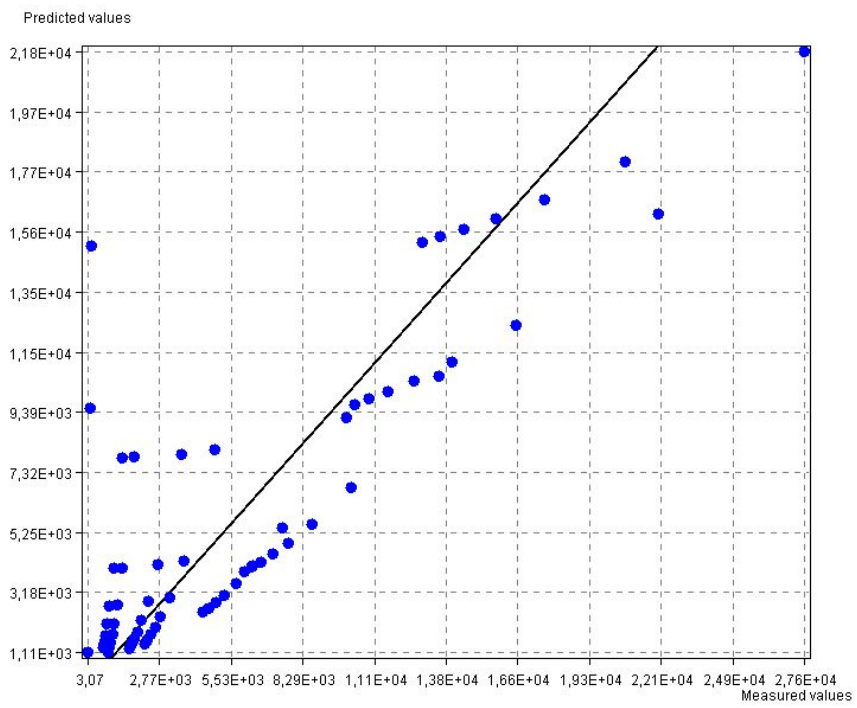

Figure S-3. Parity plot for the model used in computing the cost of the column from the reflux and the mass flow rate in the feed.

\section{COSTS FOR UNITS PER SECOND}

Investment cost of Compressors per second:

$C_{\text {Compressor }}=1.55 \cdot 10^{-4}+4.69 \cdot 10^{-10} \cdot \mathrm{W}$

Investment cost of PSA-membranes, zeolite plus vessel, per second:

$$
\begin{aligned}
C_{\text {zeolite }} & =2 \cdot \frac{\mathrm{mol}_{\mathrm{COZ}}}{\mathrm{s}} \cdot \mathrm{t}_{\text {op }} \cdot \frac{1}{S_{\text {zeolite }}} \cdot \text { Price }_{\text {zeolite }} \cdot \frac{1}{3600 \cdot 24 \cdot 365 \cdot 3} \\
C_{\text {vessel }} & =\frac{2 \cdot 9.498 \cdot V_{\text {vessel }}+12286}{3600 \cdot 24 \cdot 365 \cdot 10}
\end{aligned}
$$

Investment cost of heat exchangers with liquid stream:

$$
C_{H . E x c h .}=6.53 \cdot 10^{-11} \cdot Q
$$


Investment cost of heat exchangers with gas stream:

$C_{\text {H.Exch. }}=2.254 \cdot 10^{-9} \cdot Q$

Flash separators:

$C_{\text {vessel }}=\frac{\left(4796 \cdot \dot{V}\left(\frac{m 3}{s}\right)+10173\right)}{3600 \cdot 24 \cdot 365 \cdot 10} \cdot \frac{104}{92}$

Distillation column:

$C_{\text {column }}=\frac{\left(2799364 \cdot F_{\text {in }}+331.95 \operatorname{Ref}_{c}+152.57\right)}{365 \cdot 30 \cdot 24 \cdot 3600}$

CSTR tanks for hydrolysis and dark fermentation per second:

$C_{\text {tank }}=385 \cdot \frac{V\left(m^{3}\right)}{365 \cdot 24 \cdot 3600}$

\section{RESULTS}

Table S-3. Results of the process optimization for the production of hydrogen with different raw materials.

\begin{tabular}{|c|c|c|}
\hline Case & Base case. Corn & Wastes \\
& & \\
\hline Feed $(\mathrm{kg} / \mathrm{s})$ & 1 & 1 \\
\hline $\mathrm{H}_{2} \mathrm{SO}_{4}(\mathrm{~kg} / \mathrm{s})$ & 92.8 & 92.8 \\
\hline $\mathrm{T}_{\text {ac hydrolysis }}(\mathrm{K})$ & 453 & 453 \\
\hline $\mathrm{a}_{\text {enz hydrolysis }}$ & 1 & 1 \\
\hline $\mathrm{t}_{\text {enz hydrolysis }}(\mathrm{h})$ & 0.497 & 0.497 \\
\hline $\mathrm{t}_{\text {dark ferm. }}(\mathrm{h})$ & 69.3 & 69.3 \\
\hline $\mathrm{H}_{2}$ produced $(\mathrm{g} / \mathrm{s})$ & 7.82 & 7.82 \\
\hline $\mathrm{C}_{\text {raw material }}(\$ / \mathrm{s})$ & 0.183 & 0 \\
\hline $\mathrm{C}_{\text {enz }}(\$ / \mathrm{s})$ & 0.002 & 0.002 \\
\hline
\end{tabular}




\begin{tabular}{|c|c|c|}
\hline $\mathrm{C}_{\text {refrig }}(\$ / \mathrm{s})$ & $2.17 \mathrm{e}-6$ & $1.61 \mathrm{e}-5$ \\
\hline $\mathrm{C}_{\text {chem }}(\$ / \mathrm{s})$ & 0.037 & 0.037 \\
\hline $\mathrm{C}_{\text {power }}(\$ / \mathrm{s})$ & 0.018 & 0.018 \\
\hline $\mathrm{I}_{\text {HE }}(\$ / \mathrm{s})$ & 0.001 & 0.001 \\
\hline $\mathrm{I}_{\text {tanks }}(\$ / \mathrm{s})$ & $3.6 \mathrm{e}-3$ & $3.6 \mathrm{e}-3$ \\
\hline $\mathrm{I}_{\text {beds }}(\$ / \mathrm{s})$ & $4.2 \mathrm{e}-3$ & $4.2 \mathrm{e}-4$ \\
\hline $\mathrm{I}_{\text {comp }}(\$ / \mathrm{S})$ & $1.6 \mathrm{e}-6$ & $1.6 \mathrm{e}-6$ \\
\hline $\mathrm{I}_{\text {Total }}(\$ / \mathrm{s})$ & 0.029 & 0.029 \\
\hline $\mathrm{B}(\$ / \mathrm{s})$ & 0.009 & 0.009 \\
\hline $\mathrm{H}_{2}$ prod cost $(\$ / \mathrm{kg})$ & 37.3 & 11.89 \\
& & \\
\hline $\mathrm{ROI}(\%)$ & -803 & -166 \\
\hline
\end{tabular}

Table S-4. Results of the process optimization for the production of hydrogen under different scales.

\begin{tabular}{|c|c|c|c|c|c|c|}
\hline Case & Base Case & Case 2 & Case 3 & Case 4 & Case 5 & Case 6 \\
Scale & Scale & Scale & Scale & Scale \\
\hline Feed $(\mathrm{kg} / \mathrm{s})$ & 1 & 5 & 0.5 & 0.1 & 0.05 & 0.01 \\
\hline $\mathrm{H}_{2} \mathrm{SO}_{4}(\mathrm{~kg} / \mathrm{s})$ & 92.8 & 396.8 & 39.8 & 7.94 & 3.97 & 0.79 \\
\hline $\mathrm{T}_{\text {ac hydrolysisis }}(\mathrm{K})$ & 453 & 453 & 453 & 453 & 453 & 453 \\
\hline $\mathrm{a}_{\text {enz hydrolysis }}$ & 1 & 1 & 1 & 1 & 1 & 1 \\
\hline $\mathrm{t}_{\text {enz hydrolysis }}(\mathrm{h})$ & 0.497 & 0.497 & 0.497 & 0.497 & 0.497 & 0.497 \\
\hline $\mathrm{t}_{\text {dark ferm. }}(\mathrm{h})$ & 69.3 & 69.3 & 69.3 & 69.3 & 69.3 & 69.3 \\
\hline $\mathrm{H}_{2}$ produced $(\mathrm{g} / \mathrm{s})$ & 7.82 & 30.85 & 3.08 & 0.61 & 0.31 & 0.06 \\
\hline $\mathrm{C}_{\text {raw material }}(\$ / \mathrm{s})$ & 0.183 & 0.784 & 0.078 & 0.016 & 0.008 & 0.002 \\
\hline $\mathrm{C}_{\text {enz }}(\$ / \mathrm{s})$ & 0.002 & 0.01 & 0.001 & $2 \mathrm{e}-4$ & $1 \mathrm{e}-4$ & $2 \mathrm{e}-5$ \\
\hline $\mathrm{C}_{\text {refrig }}(\$ / \mathrm{s})$ & $1.61 \mathrm{e}-5$ & $9.3 \mathrm{e}-5$ & $6.9 \mathrm{e}-6$ & $1.8 \mathrm{e}-6$ & $9.3 \mathrm{e}-7$ & $1.9 \mathrm{e}-7$ \\
\hline
\end{tabular}




\begin{tabular}{|c|c|c|c|c|c|c|}
\hline $\mathrm{C}_{\text {chem }}(\$ / \mathrm{s})$ & 0.037 & 0.159 & 0.016 & 0.003 & $1.6 \mathrm{e}-4$ & $3.1 \mathrm{e}-4$ \\
\hline $\mathrm{C}_{\text {power }}(\$ / \mathrm{s})$ & 0.018 & 0.075 & 0.007 & 0.001 & $7.8 \mathrm{e}-4$ & $1.5 \mathrm{e}-4$ \\
\hline $\mathrm{I}_{\mathrm{HE}}(\$ / \mathrm{s})$ & 0.001 & 0.007 & $6.5 \mathrm{e}-4$ & $1.3 \mathrm{e}-4$ & $6.5 \mathrm{e}-5$ & $1.3 \mathrm{e}-5$ \\
\hline $\mathrm{I}_{\text {tanks }}(\$ / \mathrm{s})$ & $3.6 \mathrm{e}-3$ & $1.5 \mathrm{e}-2$ & $1.5 \mathrm{e}-3$ & $3 \mathrm{e}-4$ & $1.5-4$ & $3 \mathrm{e}-5$ \\
\hline $\mathrm{I}_{\text {beds }}(\$ / \mathrm{s})$ & $4.2 \mathrm{e}-3$ & $1.9 \mathrm{e}-2$ & 0.002 & $3.8 \mathrm{e}-4$ & $1.9 \mathrm{e}-4$ & $3.9 \mathrm{e}-5$ \\
\hline $\mathrm{I}_{\text {comp }}(\$ / \mathrm{S})$ & $1.6 \mathrm{e}-6$ & $6.7 \mathrm{e}-6$ & $6.7 \mathrm{e}-7$ & $1.3 \mathrm{e}-7$ & $6.7 \mathrm{e}-9$ & $1.3 \mathrm{e}-8$ \\
\hline $\mathrm{I}_{\text {Total }}(\$ / \mathrm{s})$ & 0.029 & 0.132 & 0.012 & $2.6 \mathrm{e}-3$ & $1.3 \mathrm{e}-3$ & $2.6 \mathrm{e}-4$ \\
\hline $\mathrm{B}(\$ / \mathrm{s})$ & 0.009 & 0.037 & $4.5 \mathrm{e}-3$ & $7.4 \mathrm{e}-4$ & $3.7 \mathrm{e}-4$ & $7.4 \mathrm{e}-5$ \\
\hline $\mathrm{H}_{2}$ prod cost $(\$ / \mathrm{kg})$ & 37.3 & 37.6 & 37.3 & 36.8 & 35.9 & 44.3 \\
\hline $\mathrm{ROI}(\%)$ & -803 & -752 & -750 & -749 & -724 & -930 \\
\hline
\end{tabular}

Table S-5. Results of the process optimization for the production of methanol with different raw materials.

\begin{tabular}{|c|c|c|}
\hline Case & Base case, & Wastes \\
& corn. & \\
\hline Feed $(\mathrm{kg} / \mathrm{s})$ & 1 & 1 \\
\hline $\mathrm{H}_{2} \mathrm{SO}_{4}(\mathrm{~kg} / \mathrm{s})$ & 92.8 & 92.8 \\
\hline $\mathrm{T}_{\text {ac hydrolysis }}(\mathrm{K})$ & 413 & 413 \\
\hline $\mathrm{a}_{\text {enz hydrolysis }}$ & 1 & 1 \\
\hline $\mathrm{t}_{\text {enz hydrolysis }}(\mathrm{h})$ & 0.497 & 0.497 \\
\hline $\mathrm{t}_{\text {dark ferm. }}(\mathrm{h})$ & 69.3 & 69.3 \\
\hline $\mathrm{H}_{2}$ produced $(\mathrm{g} / \mathrm{s})$ & 7.82 & 7.82 \\
\hline $\mathrm{a}_{\mathrm{PSA}}$ & 0.737 & 0.737 \\
\hline $\mathrm{CO}_{2 \text { in }}(\mathrm{kg} / \mathrm{s})$ & 0 & 0 \\
\hline
\end{tabular}




\begin{tabular}{|c|c|c|}
\hline$\frac{y_{\mathrm{H} 2}-y_{\mathrm{CO} 2}}{y_{\mathrm{CO}}+y_{\mathrm{CO} 2}}$ & 18.78 & 13.734 \\
\hline $\mathrm{P}_{\mathrm{MetOH}}$ (bar) & 50 & 50 \\
\hline $\mathrm{T}_{\mathrm{MetOH}}(\mathrm{K})$ & 473 & 473 \\
\hline Reflux ratio column & 4.68 & 4.68 \\
\hline $\begin{array}{c}\text { MetOH produced } \\
(\mathrm{g} / \mathrm{s})\end{array}$ & 38.54 & 38.54 \\
\hline $\mathrm{C}_{\text {raw material }}(\$ / \mathrm{s})$ & 0.183 & 0 \\
\hline $\mathrm{C}_{\text {enz }}(\$ / \mathrm{s})$ & 0.002 & 0.002 \\
\hline $\mathrm{C}_{\text {refrig }}(\$ / \mathrm{s})$ & $1.2 e-5$ & $1.2 e-5$ \\
\hline $\mathrm{C}_{\text {chem }}(\$ / \mathrm{s})$ & 0.037 & 0.037 \\
\hline $\mathrm{C}_{\text {power }}(\$ / \mathrm{s})$ & 0.018 & 0.018 \\
\hline$I_{\text {HE }}(\$ / \mathrm{s})$ & 0.001 & 0.001 \\
\hline $\mathrm{I}_{\text {tanks }}(\$ / \mathrm{s})$ & $3.6 e-3$ & $3.6 e-3$ \\
\hline$I_{\text {beds }}(\$ / s)$ & $2.8 e-3$ & $2.8 \mathrm{e}-3$ \\
\hline$I_{\text {comp }}(\$ / S)$ & $1.6 e-6$ & $1.6 e-6$ \\
\hline $\mathrm{I}_{\text {flash }}(\$ / \mathrm{s})$ & $2.7 e-4$ & $2.7 e-4$ \\
\hline $\mathrm{I}_{\text {Total }}(\$ / \mathrm{s})$ & 0.025 & 0.025 \\
\hline$B(\$ / s)$ & 0.014 & 0.014 \\
\hline $\begin{array}{l}\text { MetOH prod cost } \\
\qquad(\$ / k g)\end{array}$ & 6.86 & 2.12 \\
\hline ROI (\%) & -920 & -175 \\
\hline
\end{tabular}


Table S-6. Results for the production of methanol under different scales.

\begin{tabular}{|c|c|c|c|c|c|c|}
\hline Case & Base Case & $\begin{array}{l}\text { Case } 2 \\
\text { Scale }\end{array}$ & $\begin{array}{l}\text { Case } 3 \\
\text { Scale }\end{array}$ & $\begin{array}{l}\text { Case } 4 \\
\text { Scale }\end{array}$ & $\begin{array}{l}\text { Case } 5 \\
\text { Scale }\end{array}$ & $\begin{array}{l}\text { Case } 6 \\
\text { Scale }\end{array}$ \\
\hline Feed (kg/s) & 1 & 5 & 0.5 & 0.1 & 0.05 & 0.01 \\
\hline $\mathrm{H}_{2} \mathrm{SO}_{4}(\mathrm{~kg} / \mathrm{s})$ & 92.8 & 396.8 & 39.7 & 7.9 & 3.9 & 0.8 \\
\hline $\mathrm{T}_{\text {ac hydrolyisis }}(\mathrm{K})$ & 413 & 413 & 413 & 413 & 413 & 413 \\
\hline$a_{\text {enz hydrolysis }}$ & 1 & 1 & 1 & 1 & 1 & 1 \\
\hline$t_{\text {enz hydrolysis }}(h)$ & 0.497 & 0.497 & 0.497 & 0.497 & 0.497 & 0.497 \\
\hline $\mathrm{t}_{\text {dark ferm. }}(\mathrm{h})$ & 69.3 & 69.3 & 69.3 & 69.3 & 69.3 & 69.3 \\
\hline $\mathrm{H}_{2}$ produced $(\mathrm{g} / \mathrm{s})$ & 7.82 & 30.85 & 3.80 & 0.62 & 0.31 & 0.06 \\
\hline $\mathrm{a}_{\mathrm{PSA}}$ & 0.737 & 0.737 & 0.737 & 0.737 & 0.737 & 0.738 \\
\hline $\mathrm{CO}_{2 \text { in }}(\mathrm{kg} / \mathrm{s})$ & 0 & 0 & 0 & 0 & 0 & 0 \\
\hline$\frac{y_{\mathrm{H} 2}-y_{\mathrm{CO} 2}}{y_{\mathrm{CO}}+y_{\mathrm{CO} 2}}$ & 19.96 & 19.96 & 19.96 & 19.94 & 19.92 & 19.53 \\
\hline $\mathrm{P}_{\text {MetOH }}$ (bar) & 50 & 50 & 50 & 50 & 50 & 50 \\
\hline $\mathrm{T}_{\text {MetOH }}(\mathrm{K})$ & 473 & 473 & 473 & 473 & 473 & 473 \\
\hline Reflux ratio column & 4.68 & 4.68 & 4.68 & 4.68 & 4.68 & 4.68 \\
\hline MetOH produced $(\mathrm{g} / \mathrm{s})$ & 38.54 & 164.7 & 16.47 & 3.29 & 1.65 & 0.33 \\
\hline $\mathrm{C}_{\text {raw material }}(\$ / \mathrm{s})$ & 0.183 & 0.784 & 0.078 & 0.016 & 0.008 & 0.002 \\
\hline $\mathrm{C}_{\mathrm{enz}}(\$ / \mathrm{s})$ & 0.002 & 0.01 & 0.001 & $2 e-4$ & $1 \mathrm{e}-4$ & $2 e-5$ \\
\hline $\mathrm{C}_{\text {refrig }}(\$ / \mathrm{s})$ & $1.22 \mathrm{e}-5$ & $5.3 e-5$ & $5 e-6$ & $1 e-6$ & $5 e-7$ & $1 e-7$ \\
\hline $\mathrm{C}_{\text {chem }}(\$ / \mathrm{s})$ & 0.037 & 0.159 & 0.016 & 0.003 & 0.002 & $3.2 e-4$ \\
\hline $\mathrm{C}_{\text {power }}(\$ / \mathrm{s})$ & 0.018 & 0.078 & 0.008 & 0.002 & $7.8 \mathrm{e}-4$ & $1.6 e-4$ \\
\hline
\end{tabular}




\begin{tabular}{|c|c|c|c|c|c|c|}
\hline $\mathrm{I}_{\text {HE }}(\$ / \mathrm{s})$ & 0.001 & 0.003 & $5 \mathrm{e}-4$ & $1 \mathrm{e}-4$ & $4.9 \mathrm{e}-5$ & $9.7 \mathrm{e}-6$ \\
\hline $\mathrm{I}_{\text {tanks }}(\$ / \mathrm{s})$ & $3.6 \mathrm{e}-3$ & $1.5 \mathrm{e}-2$ & $1.5 \mathrm{e}-3$ & $3.1 \mathrm{e}-4$ & $1.5 \mathrm{e}-4$ & $3 \mathrm{e}-5$ \\
\hline $\mathrm{I}_{\text {beds }}(\$ / \mathrm{s})$ & $2.8 \mathrm{e}-3$ & $1.3 \mathrm{e}-2$ & $1.3 \mathrm{e}-3$ & $2.6 \mathrm{e}-4$ & $1.3 \mathrm{e}-4$ & $2.6 \mathrm{e}-5$ \\
\hline $\mathrm{I}_{\text {comp }}(\$ / \mathrm{S})$ & $1.6 \mathrm{e}-6$ & $7 \mathrm{e}-6$ & $7 \mathrm{e}-7$ & $1 \mathrm{e}-7$ & $7 \mathrm{e}-8$ & $1 \mathrm{e}-8$ \\
\hline $\mathrm{I}_{\text {flash }}(\$ / \mathrm{s})$ & $2.7 \mathrm{e}-4$ & $1.1 \mathrm{e}-3$ & $1.2 \mathrm{e}-4$ & $2.6 \mathrm{e}-5$ & $1.4 \mathrm{e}-5$ & $5 \mathrm{e}-6$ \\
\hline $\mathrm{I}_{\text {Total }}(\$ / \mathrm{s})$ & 0.025 & 0.105 & 0.011 & $2.2 \mathrm{e}-3$ & $1.1 \mathrm{e}-3$ & $2.2 \mathrm{e}-4$ \\
\hline $\mathrm{B}(\$ / \mathrm{s})$ & 0.014 & 0.024 & 0.002 & $4.9 \mathrm{e}-4$ & $2.5 \mathrm{e}-4$ & $7.9 \mathrm{e}-2$ \\
\hline $\mathrm{MetOH}$ prod cost $(\$ / \mathrm{kg})$ & 6.86 & 6.89 & 6.91 & 7.09 & 7.27 & 8.26 \\
\hline ROI $(\%)$ & -920 & -922 & -896 & -929 & -942 & -1056 \\
\hline
\end{tabular}

\section{NOMENCLATURE}

\section{Parameters and statistics of the kinetics models}

Xo

$\eta_{j 1 \text { to } j 2}$

$\varepsilon$

$X^{2}$

$\mu_{\operatorname{maxn}}$

$k_{n}$

$k_{s n}$

$k_{s n}$

$k_{s 1 n}$
Original concentration of microorganisms in dark fermentation process.

Reaction efficiency in the transformation of component $\mathrm{j} 1$ to component $\mathrm{j} 2$.

Compressor efficiency.

Chi square statistic parameter.

Maximum yield in dark fermentation reaction $\left(\mathrm{h}^{-1}\right)$

Kinetic constant of a $1^{\text {st }}$ order reactor model for reaction $\mathrm{n}(\mathrm{mol} / \mathrm{L})$

Kinetic constant of reaction $\mathrm{n}$ from Monod's model (mol/L)

$1^{\text {st }}$ Kinetic constant of reaction $n$ from Andrew's model (mol/L)

$2^{\text {nd }}$ Kinetic constant of reaction $n$ from Andrew's model (mol/L)

Modeling the cost of the distillation column

Symbols

$F_{\text {feed }}$

$N_{S}$

$q$

$R$

$R_{\min }$

$x_{\text {MetOH Feed }}$

$y_{i}$

$v_{i}$

$\Phi$

Sub-index

d

HK

LK

$r$
Total mass flow rate in the feed $(\mathrm{kg} / \mathrm{s})$.

Number of stages in the distillation column

Factor for evaluating the quality of the feed.

Reflux ratio.

Minimum reflux ratio.

Mass fraction of methanol in the feed.

Molar fraction of the component i.

Volatility of the component i.

Underwood constant.

Distillate fraction

Heavy-key component.

light-key component.

Residual fraction in the bottom of the column. 


\section{Cost for units}

Symbols

Cj

Price $_{\text {zeolite }}$

Q

$S_{\text {zeolite }}$

$t_{\text {op }}$

$\dot{V}$

$\mathrm{V}$

$V_{\text {vessel }}$

Results

B

$\mathrm{C}_{\mathrm{j}}$

$I_{j}$

$\mathrm{ROI}$

$t_{\text {enz hydrolysis }}$

$t_{\text {dark ferm. }}$.

$\mathrm{T}$

$\mathrm{y}_{\mathrm{i}}$

$a_{\text {enz hydrolysis }}$

$a_{P S A}$

Depreciation cost of unit $\mathrm{j}$ in $\$ / \mathrm{s}$.

Price of the zeolite used in the bed.

Heat flux in the heat exchanger $(\mathrm{J} / \mathrm{s})$.

Sorption capacity of the zeolite in the bed.

Operating time of the membrane.

Volumetric flux in the feed.

Volume of the tank.

Volume of the vessel in the flash and beds. Computed as described in [4].

Income by selling the product.

Cost due to term j.

Depreciation cost of term $\mathrm{j}$.

Return of Investment.

Residence time in the enzymatic hydrolysis (h).

Residence time in the dark fermentation reactor (h).

Temperature (K).

Molar fraction of component i.

Fraction of mass sent to the enzymatic hydrolysis.

Fraction of mass sent to the PSA bed

\section{REFERENCES}

[1] Han, W. Yan, Y. Shi, Y. Gu, J. Tang, J. Zhao, H. Biohydrogen production from enzymatic hydrolysis of food wate in batch and continuous systems. Scientific reports. 2016; 6: 38395. DOI: 10.1038/srep38395

[2] Almena, A. Martín, M. (2016) Technoeconomic Analysis of the Production of Epichlorohydrin from Glycerol. Ind.

Eng. Chem. Res. 2016, 55,12, 3226-3238.

[3] Cozad, A. Sahinidis, N.V. Miller, D.C. (2014) Learning surrogate models for simulation-based optimization. AIChE J. 60 (6), 2211-2227.

[4] Hernández, B. Martín, M. (2019) Optimal production of syngas via super-dry reforming. Analysis for natural gas and biogas under different CO2 taxes. Chemical Engineering Research and Design, 148, 2019, 375-392. 